Vol. 22, $n^{\circ} 1 \mid 2018$

Varia

\title{
Richard Mc Mahon, Homicide in Pre-Famine and
}

Famine Ireland

Liverpool, Liverpool University Press, 2013, 221 p., ISBN: 978184631947

1

John Carter Wood

\section{(2) OpenEdition}

Journals

Electronic version

URL: http://journals.openedition.org/chs/2215

DOI: $10.4000 /$ chs.2215

ISSN: 1663-4837

Publisher

Librairie Droz

Printed version

Date of publication: 31 October 2018

Number of pages: 147-149

ISSN: 1422-0857

Electronic reference

John Carter Wood, "Richard Mc Mahon, Homicide in Pre-Famine and Famine Ireland", Crime, Histoire \& Sociétés / Crime, History \& Societies [Online], Vol. 22, n¹ | 2018, Online since 31 December 2018, connection on 14 January 2021. URL: http://journals.openedition.org/chs/2215; DOI: https://doi.org/ $10.4000 /$ chs. 2215

This text was automatically generated on 14 January 2021.

(c) Droz 


\title{
Richard Mc Mahon, Homicide in Pre- Famine and Famine Ireland
}

Liverpool, Liverpool University Press, 2013, 221 p., ISBN: 978184631947 1

\author{
John Carter Wood
}

\section{REFERENCES}

Richard Mc Mahon, Homicide in Pre-Famine and Famine Ireland, Liverpool, Liverpool University Press, 2013, 221 p., ISBN: 9781846319471

1 In his compelling and well-written account of early-nineteenth-century Ireland, Richard Mc Mahon manages to put an examination of physical aggression on Europe's periphery at the centre of debates about European violence, the role of political or religious ideas in causing it, the success of a "civilising process" in restraining it, and the utility of evolutionary psychology in understanding it. Addressing many arguments by other historians, Mc Mahon also has a clear aim of his own: questioning the claim that Ireland in this period was "a violent society", i.e. an extraordinarily dangerous and unruly place. The author seeks to revise this view and, along the way, raises important questions about the history of violence more generally.

2 A broad quantitative chapter sets the scene for the topical inquiries that follow. In it, Mc Mahon shows that Ireland was no more a "violent society" than many other countries at the time or even today. Although Ireland had a reputation for unrest, violent outbreaks - while certainly real enough - were sporadic and localised ; overall, Irish homicide rates "were not much greater than those found in nineteenth-century England and, in the present day, in Ireland, north and south, and in Europe generally" (31). This quantitative finding shapes the rest of the book: in light of the unspectacular reality of its violence, Ireland ceases to be a distinctive historical question that demands particularly "Irish" answers. 
3 Still, there was enough violence to sustain historical interest. Mc Mahon, however, steers attention away from what have been claimed to be the main causes of serious violence in Ireland - land disputes, a distinctive "culture of honour", a desire for "recreational" enjoyment, and religio-political sectarianism - and highlights instead prosaic, "personal" motives (35). This qualitative conclusion, too, contributes to the author's aim of normalising Irish violence within the broader European experience. Mc Mahon also sees chronological continuities between the early nineteenth century and the present day that colour his conclusions in two chapters on male-on-male violence and family violence.

4 Mc Mahon sees intra-male physical aggression not primarily as evidence either of a historically distant and culturally hegemonic "honour culture" or of a widespread, distinctively Irish "recreational" legitimation of violence. Instead, he depicts it as the preserve of a particular subset of men willing to engage in violence while settling disputes and seeking local status. Similar trends shape violence today. Indeed, over the last two centuries, Mc Mahon argues, little has altered about the motivations for or nature of such violence; what has mainly changed is the likelihood of it leading to fatalities (as a result of progress in medical care) and to official state responses (because of the growth of police and judicial institutions).

5 Mc Mahon also finds relatively little family violence. The rates of intra-family homicide in Ireland in the first half of the nineteenth century were "not much higher" and in some places "lower than the present day" (83), again stressing historical continuities. As with intra-male homicide, Mc Mahon sees the motivations for and contexts of most family violence less as the result of uniquely Irish cultural factors and more as deriving from tensions and disagreements common to other European contexts, whether past or present.

6 Unusually for a historical study of this kind, Mc Mahon addresses analytical perspectives on violence from the field of evolutionary psychology. He finds some evidence in his sources for the claim that male-on-male violence arises from an evolved, sex-specific psychology. But he finds little support for evolutionary psychological views in the records of Irish family violence: killings of women resulting from male sexual jealousy and those of step-children were rare, in contrast to the stress on such contexts by evolutionary psychologists. Mc Mahon goes further, suggesting evolutionary theory sets up "unfalsifiable" claims and reproaching its advocates for ignoring contrary explanations (87). Moreover, he doubts whether historians should (or even could) deal with phenomena claimed to be "beyond culture", and he insists that evolutionary psychology itself should be seen as a specific cultural product. Ultimately, Mc Mahon accepts a biological basis for the universal male predominance in violence but denies that physical aggression is "invariably guided by the pursuit of [reproductive] fitness" (88).

7 Mc Mahon's last two main chapters turn to what have been taken as leading causes of violence and unrest in early-nineteenth-century Ireland: land disputes and sectarianism. Mc Mahon's downplaying of Irish violence (at least its homicidal forms) reappears here. Without denying widespread tensions between landlords and tenants, Mc Mahon argues that violence - and its threat - played a much smaller role in them than has often been claimed. Admitting that it was "significant in certain conditions and locations", he nevertheless stresses that violence was "not a central element in the regulation of the use and occupation of land" and that rural relationships were shaped 
as much by efforts to avoid it as to deploy it (93). This emphasis on the systematic cultural restraint of violence offers a fruitful avenue for further research. Similar conclusions also apply to religious and political sectarianism, often seen as perhaps the distinctively Irish causal factor in violent conflict. As in other contexts, Mc Mahon finds that while there were incidents of violence motivated by religious and political tensions, these did not signify a general characteristic of Irish society.

8 As the foregoing summary suggests, the author is able to tie his detailed empirical research - skilfully balancing quantitative and qualitative approaches - to broader historiographical arguments and themes. His stress on the comparatively typical level of homicide in Ireland contributes to efforts to compare levels of violence in more economically advanced to those in more "peripheral" regions. His doubts about the influence of religious sectarianism or property conflicts in an oppressive colonial culture help to link Irish homicide patterns into a broader pool of "everyday" violence within Europe. His claims about continuities between the early nineteenth century and the present day seek to question notions of a "civilising process". And his stress on serious violence as the product of a distinctively male subgroup both raises questions about the significance of distinctive honour cultures and suggests the relevance of more universalist theories to explaining some forms of homicide.

9 As someone who has urged historians to engage with explanations of violence emerging from biological sciences in general and evolutionary psychology in particular, I find Mc Mahon's efforts on this point welcome. I have reservations, however, about some of his conclusions. First, while (correctly) stating that evolutionary psychology is not an explicit "theory of motivation" (84), Mc Mahon nevertheless employs it as such, seeing it (wrongly) as postulating an explicit "concern with "fitness"' as "the driving force behind violence" (86). Fitness, however, is relevant at the "ultimate" level of explaining the past emergence of "proximate" motivations for behaviour that, in themselves, might not directly seek it ; in some instances, and in some modern contexts, these behaviours might even seem to contradict a rational accounting of "fitness" outcomes. This is a vital distinction in evolutionary reasoning. Second, the argument that there are "limits" to "culture" - made by myself and others - was not meant to deny the influence of culture or to claim that evolutionary (or any other) scientific perspectives on human behaviour developed "outside" of history. The aim, rather, has been to critique an understanding of "culture", widespread in the social sciences and the humanities, as something self-contained, all-encompassing, and independent of biology. The claim was not that culture is meaningless but that the effort to explain behaviour through the all-purpose independent variable of "culture" is inevitably handicapped by a failure to account for possibly "innate" predispositions, i.e., those that exist in human psychology prior to experience and encourage particular kinds of thought and behaviour (and, thus, forms of "culture"). Many "cultural" phenomena - such as efforts to control or suppress male propensities to violence - may well emerge as responses to such innate predispositions themselves. This viewpoint, actually, seems to fit well with at least some of Mc Mahon's findings.

Some of his other attempted theoretical revisions - while compelling - also need to be considered carefully. For example, his study begins after the point at which the largest reductions in homicide associated with a "civilising process" have been postulated. Moreover, given the small overall number of homicides with which he deals, his critiques of evolutionary psychological arguments based on the low number women 
clearly killed by "jealous" men or of step-children killed by their families might be overstated.

11 Nonetheless, this is an important and compelling addition to the historiography of European violence. The book effectively combines quantitative and qualitative methods, carefully disaggregates violence into the main contexts in which it arose, and offers a strong comparative angle that enhances the values of this specific case study. In the clarity and thoughtfulness of his argumentation and writing, Mc Mahon has set a very high standard for the history of violence.

\section{AUTHORS}

\section{JOHN CARTER WOOD}

Johannes Gutenberg University, Mainz (Germany)

woodjo[at]uni-mainz.de 